\title{
Application of Remote Sensing in Agriculture \& Animal Husbandry, ICT Programmes in Livestock Development Problems \& Prospect of ICT in Livestock Development
}

\author{
S. Senapati, A. Paikaray, B.C. Das, P. Swain \\ Department of Veterinary \& Animal Husbandry Extension, Orissa University of Agriculture \& Technology, Bhubaneswar- \\ 751003, Odisha, India
}

\begin{abstract}
Remote sensing technology has rapidly expanded for the development of diffident sectors including agriculture and allied fields. The remote sensing techniques will continue to be very important factor in the improvement of present system of acquiring agricultural data. The remote sensing provides various platforms for agricultural and animal husbandry survey. The importance of remote sensing applications to agricultural and allied sectors involve land use pattern, crop production crop yield determination, livestock population, sex of animal, types of farm and distribution of animals. ICTs are emerging as an important tool for the development of societies and have driving forces in the economics world-wide. ICTs are no more confined to assist high -end research and development, the new technologies have made significant improvements in the life styles and the efficiency levels of agriculture and animal husbandry sectors of the economy.

Keywords- Remote Sensing, Geographical Information System (GIS), Information and Communication Technology (ICT),Web-GIS based Livestock Information Management System (WGLIMS), LANDSAT.
\end{abstract}

\section{INTRODUCTION}

Beyond the primitive method of remote sensing technology, our earliest ancestors used to standing on a high mountains or tree to view the landscape of the area. The modern discipline arose with the development of flight. The balloonist mode photographs of cities from their balloons. The first tactical use was during the civil war. The introduction of online web services for easy access to remote sensing data in the $21^{\text {st }}$ century mainly low/mediumresolution images, like Google Earth, has made remote sensing more familiar to the every one and has popularized the science.

Remote Sensing
Remote Sensing is a technical process of procuring information about distant objects by technological means without any physical contact. The term remote sensing was first used in 1960. The scientific means include various sensors. The remote sensing is based on the fact that every object on the earth surface reflects a specific wavelength characteristic of the reflecting surface and is called spectral signature of the object. This reflectance from each object depends on the wavelength of incident radiation, molecular structure of the object and its surface conditions Besides this, every object on the earth's surface has finite temperature, greater than absolute zero and therefore radiates energy according Stefan Boltzmann's law. Remote sensing is mainly based on measuring electromagnetic energy. (Ghadekar, 2001)

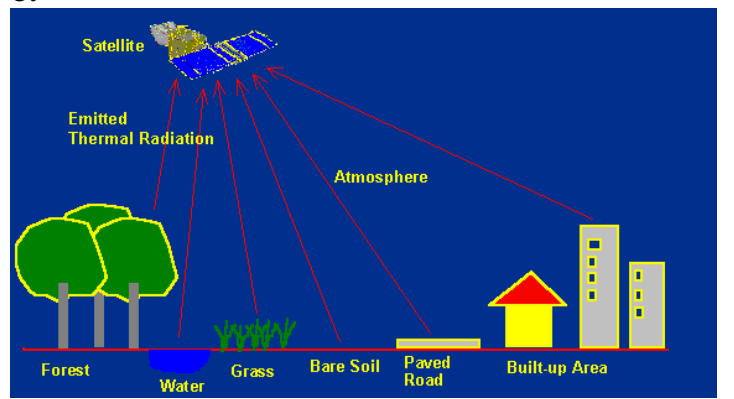

Fig.1: Principle of remote sensing model, Source: CRISP

Remote sensing has now become an import tool for procuring information, surveillance, explorations, management, inventory in various fields like agriculture, animal husbandry, forestry etc. It has further enabled monitoring of environment and thereby helping in conservation. In the last four decades it has grown as a major tool for collecting information on almost every aspect on the earth. On the basis of availability of very high spatial resolution satellites in the recent years, the applications 
have multiplied. In India remote sensing has been used for various applications during the last four decades and has contributed significantly towards development.

\section{Application on Agriculture}

Agriculture is the backbone of Indian economy and the pivotal sector for ensuring food security. Timely availability of information on agriculture is vital for taking informed decisions on food security issues. India is one of the few countries in the world that uses space technology and landbased observations for generating regular updates on crop production statistics and providing inputs to achieve sustainable agriculture.

Crop production database is used to know how many acres of land have been cultivated, where cultivation already covered and where need to be done, i.e. area and production of different crops can be assed with help of remote sensing and GIS applications. Crop distribution help in modeling of climatic and other environmental changes and their effects on agriculture.

Identification of various crops from remote sensing techniques can be done. The electromagnetic energy receipts from various species of crops will definitely vary. Qualitative evaluation of computer processed LANDSAT data shows that major crops species can be identified. Such experiment to identify groundnut and paddy fields were carried out in Andhra Pradesh (MANAGE, 2008))

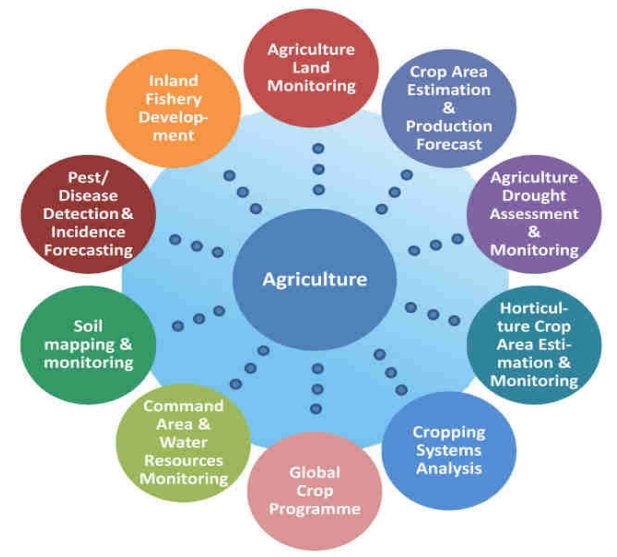

Fig.2: Agricultural parameters estimated through remote sensing

After identifying crop species, by superimposing geographical boundary of a region, estimation of acreage under each type of class is obtained. Crop acreage estimation by remote sensing technique and accounts available from Bureaus of Economics has shown good agreement. For better performance and management, monitoring of the crops at frequent intervals during crop growing season is required. Space based remote sensing enables to monitor the crop repetitively. The condition of crop is mainly influenced by the following types of stress and disturbances.
a. Moisture Stress
b. Nutrient stress
c. Flooding
d. Salinity
e. Disease and pest attack etc.

Remote sensing also employed in determining land use patterns, flood prone area mapping, monitoring desertification, land use mapping, soil mapping. Thus the remote sensing plays important role in agriculture for various objects and processes.

\section{GIS in Agriculture}

GIS and Remote Sensing have emerged as very significant information technology tools to boost the overall efficiency of agricultural sector. Various Governmental and semiGovernmental agencies are involved in research and development activities and comprehensive database for agricultural sector can ensure greater reliability of estimates and forecasting. This in turn can be used for effective agricultural planning and broad policy making.

Efforts to improve and harness latest remote sensing and information technology techniques to capture, collate, add value and disseminate data into appropriate destinations will be helpful for managing risk and in accelerating the growth process of agricultural sector.(Varshneya and Pillai, 2003) Geospatial analysis, the study of various geographic features, different weather conditions and the relationships that exist among these can be applied to many areas of the agricultural industry. By better understanding how features within the landscape interact, decision makers can optimize operational efficiency and improve economic returns. GIS is becoming fully integrated and widely accepted for helping government agencies to manage programs that support farmers and protect the environment. GIS can be used effectively for

a. Cropping pattern monitoring

b. Agricultural Planning and market analysis

c. Soil Management

d. Yield modeling and estimation

\section{Application on Animal Husbandry}

India primarily an agricultural economy country. The population of rural India depends on livestock like Dairy Cattles, Poultries, Small animal as goat etc. The livestock population of India is huge and animals as a whole play an important role in the agricultural economy even though they often receive inadequate nourishment. The objective of animal husbandry programme is to increase the supply of 
milk, meat and eggs, a greater consumption of which is very essential in order to balance the present customary diets and to provide efficient bullock power for agricultural operations in every part of the country. The quality of the cattle is thus of critical importance to the rural economy. There are also certain animal products such as wool, hair, hides and skins etc., the efficient utilization of which as industrial raw materials has a growing economic significance. Animal husbandry programme continues to encounter serious practical difficulties, for which the size and the nature of the problem and its essential features needs to be understood. Livestock Management involves the overall productivity, management, improvement and planning for livestock resources for each and every region of the country.

Livestock play an important role in developing countries. The control of livestock diseases depends on a clear understanding of the diseases present, their distribution and impact. Livestock Management in any country involves welfare and sustainable development of livestock to build a progressively modern and dynamic livestock-linked agricultural economy for attaining self-sufficiency and import substitution, gaining export competitiveness, dispersed development to reduce regional imbalance. There were about 343 millions of cattle in our country during the year 1965-66. Out of these 176 million were sheep, 64 million were goats and the rest were others. In 2001 there were an estimated 219.6 million head of cattle, representing about $15 \%$ of the world's total and more than in any other country. There are eight breeds of buffalo, 26 cattle breeds, and numerous crossbreeds. The bovine inventory in 2001 also included 94.1 million buffalo. Other livestock in 2001 included 123.5 million goats, 58.2 million sheep, 17.5 million hogs, 900,000 camels, 750,000 Ass, 800,000 horses, and 735 million chickens. Bullocks (steers) and water buffalo are important draft animals. (Ranad and Mishra, 2015)

Dairy farming in India is undertaken on so many of small farms, where only average of three milk animals are raised on less than a hectare ( 2.5 acres), and yields consist of two to three liters of milk daily. To improve milk production, a dairy development program was begun in 1978 to build up the milch herd to 150 million crossbred cows. Milk output in 2001 from over 35 million dairy cows was estimated at 37.1 million tons, second in the world. Egg production in 2001 was 1,906,000 tons. The production of cattle and buffalo hides and goat and sheepskins is a major industry. About 53,700 tons of wool was produced in 2001. Silk production that year amounted to 15,000 tons, second highest after China. (Ranad and Mishra, 2015)
Right approach is needed to improve the information systems through the introduction and use of active surveillance for the rapid, inexpensive collection of accurate animal health data, and the use of GIS to improve data management and incorporate the spatial component of their distribution. The advantages of spatial domain are location studies / map based studies of livestock enables the planners to effectively manage the livestock resources in the country.

\section{GIS in Animal Husbandry}

GIS plays an important role in animal husbandry. They are also carrying the responsibilities like training the farmers and professionals, strengthening of semen stations, Organization of infertility camps, to deliver breeding inputs at farmer's door steps. Until recently significant efforts are put in the direction of livestock survey and data generation by various agencies. These data should be given a Geoinformatics approach / direction, which will result in deriving lotof information from the existing surveyed data. Development \& implementation of Web-GIS based Livestock Information Management System (WGLIMS) is very much essential to collect, analyze, model, visualize and disseminate data available on livestock in India. Use of GIS can handle and analyze spatially referenced data and offers tremendous potential in storing voluminous spatial and nonspatial data. By employing GIS, GPS and remote sensing technologies advantages can be sought not only in time and costs, but also in a more comprehensive and integrated treatment for affected areas and their restoration, in a mainly agrarian economy of developing country like India. (Sajeevanet. al., 2012)

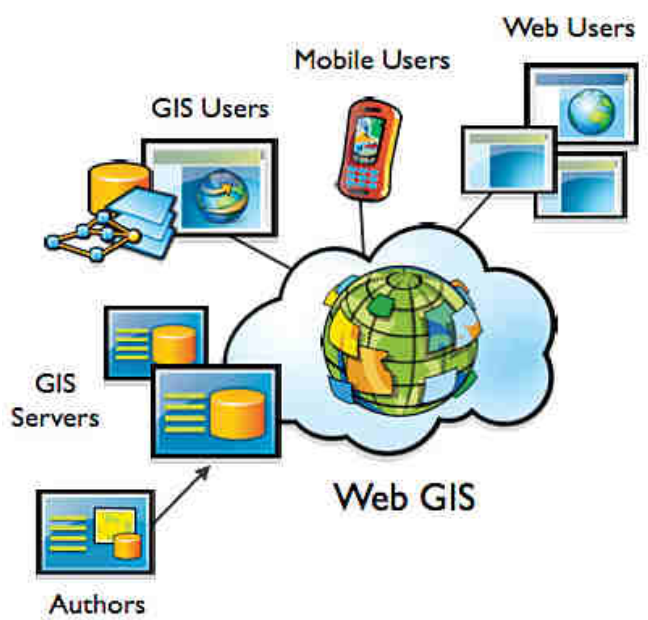

Fig.3: Web GIS based Livestock Information Management System model

\section{ICT Programmes in Livestock Development}

Using GIS complete livestock geo-database can be created. This can be very helpful in getting information about 
number of bulls, cows, poultry birds, buffaloes, milch animals in any village at a click of a button. Also Geodatabase can be created for sheep breading farms for Exotic / Local / Cross Breed sheep within states, Locations of semen stations \& frozen semen laboratories. Locations convenient to sheep rearing, Locations where cross breeding has been undertaken for upgradation of local sheep can be identified. Livestock Insurance Scheme is being implemented by Central Government in various states. Progress and extent of implementation can be integrated over spatial features using GIS.

Today, the artificial insemination has become a normal method of breeding quality cattle. A large number of cows and buffaloes are inseminated artificially. The technique of artificial insemination (AI) is particularly more useful in a country like India where the paucity of quality sires has been the main hurdle in the way of cattle improvement. Geo-Database of these centers can be created using GIS technique. These centers can be displayed spatially.

a. This spatial distribution of Artificial Insemination centers will give immediate idea about their distribution in complete state/nation.

b. This will help to identify districts where number of such centers are less or almost none and special programme can be undertaken to increase the number.

c. Distribution of future centers can be decided

d. All the data related to each centers such as Responsible authority, number and types of animals which are artificially inseminated, efficiency of center etc can be integrated with spatial location.

\section{Problems of ICT in Livestock development}

Several studies have analyzed the factors affecting the adoption of modern technologies and practices in agriculture sector including animal husbandry (Agwu and Anyanwu 1996) where the producers' characteristics such as age, education, social category and income, and farm characteristics such as size of landholdings, number of crops grown and purpose of agriculture \& livestock were investigated as important factors that affect the information adoption in agricultural decisions. In the present study, the relationship between frequency of ICT based information used in livestock decision-making and socio-demographic profiles of livestock farmers is analyzed using Spearman Rank Correlations. (Ali, 2015)

Table.1: Spearman's rho Correlations Matrix between use of ICT and socio-demographic factors

\begin{tabular}{|c|c|c|c|c|c|c|c|c|c|}
\hline Variables & $\begin{array}{c}\text { Numb } \\
\text { er of } \\
\text { times } \\
\text { ICT } \\
\text { used }\end{array}$ & $\begin{array}{l}\text { Age, } \\
\text { Year } \\
\text { s }\end{array}$ & $\begin{array}{c}\text { Educationle } \\
\text { vel }\end{array}$ & $\begin{array}{c}\text { Social } \\
\text { Catego } \\
\text { ry }\end{array}$ & $\begin{array}{c}\text { Incomele } \\
\text { vel }\end{array}$ & $\begin{array}{l}\text { Operationala } \\
\text { nd-holdings }\end{array}$ & $\begin{array}{l}\text { Numb } \\
\text { er of } \\
\text { Crops }\end{array}$ & $\begin{array}{c}\text { Farmi } \\
\text { ng \& } \\
\text { livesto } \\
\text { ck as } \\
\text { busine } \\
\text { ss }\end{array}$ & $\begin{array}{l}\text { Membersh } \\
\text { ip in } \\
\text { Farmers' } \\
\text { Organizati } \\
\quad \text { on }\end{array}$ \\
\hline $\begin{array}{l}\text { Number of times } \\
\text { ICT used }\end{array}$ & 1.00 & & & & & & & & \\
\hline Age, Years & 0.04 & 1.00 & & & & & & & \\
\hline $\begin{array}{l}\text { Education } \\
\text { level,High School \& } \\
\text { above }=1, \\
\text { otherwise }=0\end{array}$ & $0.21 * *$ & $\begin{array}{c}- \\
0.13 \\
* *\end{array}$ & 1.00 & & & & & & \\
\hline $\begin{array}{l}\text { Social } \\
\text { Category,General } \\
=1 \text {, otherwise }=0\end{array}$ & $0.12 *$ & $\begin{array}{c}- \\
0.01 \\
2\end{array}$ & $0.19 * *$ & 1.00 & & & & & \\
\hline $\begin{array}{l}\text { Incomelevel, >Rs. } \\
3000=1 \text {, } \\
\text { otherwise }=0\end{array}$ & $0.12 *$ & -0.03 & $0.20 * *$ & $0.14 * *$ & 1.00 & & & & \\
\hline $\begin{array}{l}\text { Operationallandhold } \\
\text { ings, ha }\end{array}$ & $0.16^{* *}$ & -0.04 & $0.29 * *$ & $0.16^{* *}$ & $0.24 * *$ & 1.00 & & & \\
\hline Number of Crops & $0.23 * *$ & -0.05 & $0.33 * *$ & $0.17 * *$ & $0.17 * *$ & $0.34 * *$ & 1.00 & & \\
\hline Farming and & $0.14 * *$ & 0.01 & 0.020 & 0.046 & -0.031 & $0.24 * *$ & 0.077 & 1.00 & \\
\hline
\end{tabular}




\begin{tabular}{|c|c|c|c|c|c|c|c|c|c|}
\hline $\begin{array}{l}\text { livestock as } \\
\text { business, Yes=1, } \\
\mathrm{No}=0\end{array}$ & & 5 & & & & & & & \\
\hline $\begin{array}{l}\text { Membership in } \\
\text { Farmers' } \\
\text { Organization, Yes }=1 \\
, \text { No=0 }\end{array}$ & 0.07 & $\begin{array}{c}- \\
0.01 \\
5\end{array}$ & $0.18 * * *$ & -0.019 & $0.17 * *$ & $0.091 *$ & $0.25 * *$ & -0.059 & 1.00 \\
\hline $\begin{array}{l}\text { SHG } \\
\text { Membership, Yes=1, } \\
\text { No=0 }\end{array}$ & 0.018 & 0.03 & 0.004 & -0.049 & -0.008 & 0.020 & $0.15^{* *}$ & 0.014 & $0.31 * *$ \\
\hline
\end{tabular}

The results of rank correlation analysis are presented in Table 4, which clearly indicate that use of ICT based information is positively and significantly related with the operational landholdings $(\mathrm{p}<0.01)$, education $(\mathrm{p}>0.01)$, social category $(p>0.05)$, income level $(p>0.05)$, number of crop grown $(\mathrm{p}>0.01)$ and considering farming and livestock as business $(p>0.01)$. This implies that education, social category and income of the farmers are important sociodemographic factors affecting the adoption of ICT based information system. Similarly, farmers with larger landholdings, cultivating more number of crops in a year and considering farming and livestock as business venture are more likely to use ICT based information for livestock decision-making.

\section{Prospect of ICT in Livestock Development}

The major characteristics of quality information are relevance, accuracy, sufficiency and timeliness of service delivery for better decision-making. Quality information plays a pivotal role in enlightening and raising the level of knowledge of livestock farmers on best practices across the value chain. The quality perceptions of the farmers on various aspects of animal husbandry were recorded on a five point likert scale. The results of mean scores of information quality and analysis of variance between users and non-users of ICT based information sources on 8 dimensions of livestock decision-making are given in Table 3 . The results on mean value of responses on various livestock practices are less than 3 in most of the cases, which clearly indicate that farmers are receiving quality information for livestock decision-making. The results also indicate that the mean scores on all the parameters of livestock rearing are lower in case of ICT users as compared to non-users. In order to analyze the difference in quality of information received by them, analysis of variance (ANOVA) has been carried out. Results of the analysis indicate that the value of F-statistics are significant at $1 \%$ level of significance for most of the production related decisions such as breeding, feeding, healthcare and livestock production management. The usage level of this information is also comparatively higher as compared to information usage on processing and marketing of livestock based products.

Table.2: ANOVA on quality of information on animal husbandry

\begin{tabular}{|c|c|c|c|c|c|c|c|}
\hline \multirow[t]{2}{*}{ Livestock activities } & \multicolumn{3}{|c|}{ ICT based } & \multicolumn{3}{|c|}{ Non-ICT based } & \multirow[t]{2}{*}{ F-value } \\
\hline & $\mathbf{N}$ & Mean & $\begin{array}{c}\text { Std. } \\
\text { Deviation }\end{array}$ & $\mathbf{N}$ & Mean & $\begin{array}{c}\text { Std. } \\
\text { Deviation }\end{array}$ & \\
\hline Breeding & 101 & 1.82 & 0.79 & 172 & 2.68 & 0.72 & $83.50 * * *$ \\
\hline Feeding & 102 & 1.87 & 0.80 & 184 & 2.55 & 0.66 & $59.83 * * *$ \\
\hline Livestock healthcare & 104 & 1.96 & 0.87 & 224 & 2.73 & 0.63 & $82.94 * * *$ \\
\hline Livestock management & 59 & 2.19 & 0.75 & 135 & 2.60 & 0.66 & $14.76^{* * *}$ \\
\hline Milking techniques & 57 & 2.54 & 0.85 & 118 & 2.83 & 0.71 & $5.53 * *$ \\
\hline Quality management & 52 & 2.42 & 0.85 & 105 & 2.75 & 0.79 & $5.83 * *$ \\
\hline Market price analysis & 54 & 2.17 & 0.75 & 117 & 2.38 & 0.64 & $3.84 *$ \\
\hline Marketing \& selling & 53 & 2.09 & 0.77 & 115 & 2.36 & 0.65 & $5.25 * *$ \\
\hline
\end{tabular}


very poor $=5$

The adoption of milking technique, quality management of livestock products due to highly perishable nature, market price analysis and marketing and selling are critical areas of decision-making for the livestock farmers. However, the usage of information on these post-harvest practices is comparatively lower among both ICT users and non-users. Nonetheless, it is evident from the findings that the users of ICT based information are getting better quality information and are hence making significantly better decisions on all aspects of livestock farming. This implies that there is a huge potential to increase the quality of information delivery by adopting modern technologies.(Ali J. 2011)

\section{CONCLUSION}

The use of remote sensing technology has rapidly expanded for the development of diffident sectors including agriculture and allied fields. The remote sensing techniques will continue to be very important factor in the improvement of present system of acquiring agricultural data. The remote sensing provides various platforms for agricultural and animal husbandry survey. Satellite imagery has unique ability to provide the actual synoptic views at large area at a time, which is no possible for conventional survey methods and also the process of data acquisition and analysis are very fast through Geographical Information System (GIS) are compared to the conventional methods. The importance of remote sensing applications to agricultural and allied sectors involve land use pattern, crop production crop yield determination, livestock population, sex of animal, types of farm and distribution of animals.

The WGLIMS will be very useful for monitoring, analysis $\&$ disseminate information on livestock of India. WGLIMS will have spatial database of various livestock, which will be linked to the requisite attributes for visualization and analysis. WGLIMS will help in planning, decision making on various conservation \& nutritive measures through objective analysis. The system, if implemented, will acts as base to analyze, visualize and adopt suitable measures for various livestock in India and in future, the same system may be adopted by developing countries to implement the system respectively.

\section{REFERENCES}

[1] Agwu, A.E. and A.C. Anyanwu (1996), "Sociocultural and Environmental Constraints in Implementing the NALDA Programme in South Eastern Nigeria: A Case Study of Abia and Enugu States", Journal of Agriculture, Technology and Education, Vol. 1, No. 2, pp. 68-72.
[2] Ali, J. (2011). Use of quality information for decisionmaking among livestock farmers: Role of Information and Communication Technology, Livestock Research for Rural Development 23 (3)

[3] Animal husbandary, available at http://nationsencyclopedia.com/ Asia-andOceania/India-animalhusbandry.html, accessed during January 2015.

[4] Ghadekar,S.R. (2001): Remote Sensing and its application in agriculture. Meteorology, Agromet Publishers, 52 B, Indraprasth, Dharampeth, Nagpur, $4^{\text {th }}$ Edition $p: 174-184$.

[5] Livestock Management in Arid Rangelands: Remote Sensing \& GIS Applications, The University of the Western Cape, Department of Biodiversity and Conservation

Biology,http://cdioinstitute.org/papers/Day4/Livestock $\% 20$ Management\%20in\%20Arid\%20Rangelands.pdf

[6] MANAGE, 2008: Information \& Communication Technology in Agriculture, PGDAEM Study Materials. Government of India, Hyderabad. India

[7] Plan launch, available at http://planningcommission.nic.in/plans/planrel/fiveyr/ 2nd/2planch14.html, accessed during January 2015.

[8] Ranad, P. and Mishra, A. (2015).Web-GIS based livestock information management system(WGLIMS): Review of Indian scenario. Int. Journal of Applied Sciences and Engineering Research 4 (2)

[9] Sajeevan, G., Mhatre, J., Ranade, P., Dutta, U., and Londhe, S. (2012). GRIMMS Web -Connecting India, published in Geospatial Today Magazine.

[10] Varshneya, M.C. and Pillai, P.B., (2003): Remote Sensing. Text Book of Agricultural Meteorology.ICAR Public. P: 191. 